\title{
Personal Branding Ganjar Pranowo untuk Membangun Komunikasi Politik di Media Sosial Instagram
}

\author{
Syifaur Rahmah \\ Universitas Budi Luhur Jakarta, Jakarta \\ Email: syifaur1696@gmail.com
}

\begin{abstract}
Political actors use social media to increase public trust in them and build an image in the eyes of society. Personal branding carried out by politicians on social media will shape people's perceptions of themselves and make it easier for them to conduct political communication. Ganjar Pranowo is a political actor who actively uses social media to interact with his people. Instagram is one of the social media that he uses to facilitate two-way communication with the community by carrying out his characteristics and forming an image of himself which will then make it easier for him to carry out political communication. This article aims to explain the personal branding strategies used by Ganjar Pranowo to build political communication through his feeds on social media Instagram based on four personal branding formation and development strategies. This article uses a descriptive qualitative approach with the result is that Ganjar Pranowo has implemented a personal branding formation strategy through four successful strategies to make Ganjar Pranowo closer to the community and build people's trust in him. Ganjar Pranowo's efforts in building personal branding through social media brought results that influenced Ganjar Pranowo's image in the eyes of the public as evidenced by the election of Ganjar Pranowo as Governor of Central Java for two terms.
\end{abstract}

Keywords: mass media, personal branding, political communication

\begin{abstract}
ABSTRAK
Media sosial dimanfaatkan oleh para aktor politik untuk meningkatkan kepercayaan masyarakat terhadap mereka dan membangun image di mata masyarakat. Personal branding yang dilakukan oleh politisi di media sosial akan membentuk persepsi masyarakat akan dirinya dan memudahkan mereka untuk melakukan komunikasi politik. Ganjar Pranowo merupakan salah satu aktor politik yang aktif menggunakan media sosial untuk berinteraksi dengan masyarakatnya. Instagram menjadi salah satu media sosial yang digunakannya untuk memudahkan komunikasi dua arah dengan masyarakatnya dengan membawa ciri khas yang dimilikinya dan membentuk image tentang dirinya yang kemudian akan memudahkannya dalam melakukan komunikasi politik. Artikel ini bertujuan untuk menjelaskan strategi-strategi personal branding yang dilakukan oleh Ganjar Pranowo untuk membangun komunikasi politik melalui unggahannya di media sosial Instagram berdasarkan empat strategi pembentukan dan pengembangan personal branding. Penelitian ini menggunakan pendekatan kualitatif deskriptif dengan hasil dari penelitian ini adalah Ganjar Pranowo telah melakukan strategi pembentukan personal branding melalui empat strategi yang sukses membuat Ganjar Pranowo menjadi lebih dekat dengan masyarakat dan membangun kepercayaan masyarakat terhadap dirinya. Usaha Ganjar Pranowo dalam membangun personal branding melalui media sosial membawa hasil yang memengaruhi image Ganjar Pranowo di mata masyarakat terbukti dengan dipilihnya Ganjar Pranowo sebagai Gubernur Jawa Tengah selama dua periode.
\end{abstract}

Kata Kunci: media massa, personal branding, komunikasi politik.

\section{Pendahuluan}

Internet kini menjadi salah satu hal penting

dalam bermasyarakat seiring dengan berkembangnya

teknologi. Internet memunculkan adanya jenis media baru yang dinamakan new media atau media baru. Media baru adalah salah satu bentuk dari media massa yang berbasis digital. Mondry dan Risman (2016) menjelaskan bahwa media massa adalah salah satu 
bentuk media informasi yang terkait dengan masyarakat serta berfungsi untuk berhubungan dengan khalayak (masyarakat) secara umum serta dikelola dengan profesional dan bertujuan untuk memperoleh keuntungan. Sedangkan Effendy (2003:65) menjelaskan bahwa media massa digunakan dalam suatu komunikasi jika komunikan pada komunikasi tersebut berjumlah banyak dan bertempat tinggal jauh.

Media sosial menjadi salah satu bentuk media massa yang paling banyak diminati sebab media sosial menawarkan penyampaian informasi yang lebih cepat dan komunikasi dua arah yang membuat penggunanya dapat saling berinteraksi satu dengan yang lainnya secara daring. Media sosial merupakan media untuk bersosialisasi sehingga memiliki kekuatan untuk mempengaruhi masyarakat lebih cepat karena ketergantungan masyarakat terhadap apa yang diinformasikan melalui media sosial.

Kekuatan media sosial tersebut kemudian dimanfaatkan oleh para aktor politik untuk meningkatkan kepercayaan masyarakat terhadap mereka dan membangun image di mata masyarakat. Para aktor politik menjadikan media sosial sebagai suatu sarana yang ideal untuk berkomunikasi dengan masyarakat seperti mengetahui apa yang masyarakat inginkan dan butuhkan, memengaruhi, mengajak, memberi informasi kepada masyarakat melalui apa yang mereka bagikan di media sosial mereka. Komunikasi tersebutlah yang dinamakan dengan komunikasi politik. Komunikasi politik adalah salah satu bagian dari kegiatan politik yang memiliki tujuan untuk menyampaikan pesan-pesan yang bercirikan politik dan dilakukan oleh politikus kepada sasaran politik. Komunikasi politik biasanya lebih kencang dilakukan oleh para aktor politik saat melakukan kampanye. Strategi kampanye biasanya dilakukan melalui pengumpulan massa atau mendatangi langsung, namun dapat pula melalui media seperti baliho, poster, bendera, media massa cetak maupun elektronik bahkan media internet (Anshori, 2018).
Beberapa penelitian mengungkapkan bahwa para aktor politik di seluruh dunia telah memanfaatkan media sosial untuk menjalin hubungan dengan konstituen, membentuk diskusi politik, dan berdialog secara langsung dengan masyarakat (Anshari, 2013). Burke (2000:380) dalam Susanto (2017) menerangkan bahwa jaringan komunikasi politik yang terbentuk dengan menggunakan media sosial adalah alasan yang praktis untuk dapat menumbuhkan partisipasi yang mendorong kontribusi, umpan balik, adanya keterbukaan tanpa jarak antar sumber berita, serta khalayak yang mampu menguatkan diskusi.

Saat ini, media sosial adalah cara yang terbaik dan termudah untuk menumbuhkan identitas pribadi, membangun reputasi, dan menjadi terlihat dalam industri tertentu. Dengan demikian, seperti yang dijelaskan oleh Dalla-Camina (2016) dalam Huffington Post, siapapun dapat membuat akun untuk kemudian mempromosikan aktivitasnya agar mendapatkan lebih banyak pengikut dan membentuk cara agar mereka dapat dilihat secara online dengan menggunakan sedikit usaha (Petruca, 2016). Oleh karena itu, media sosial dapat dimanfaatkan oleh para penggunanya untuk membentuk personal branding dan menjangkau khalayaknya lebih luas tanpa harus mengeluarkan usaha yang lebih. Personal branding yang dilakukan oleh politisi di media sosial akan membentuk persepsi masyarakat akan dirinya dan memudahkan bagi para politisi untuk melakukan komunikasi politik. Kaplan \& Haenlein (2010) menyebutkan bahwa jika biasanya upaya branding membutuhkan dukungan finansial yang besar untuk promosi, maka media sosial menawarkan kesempatan kepada seseorang untuk mempromosikan dirinya sebagai merek dengan cara yang lebih murah (Petruca, 2016). Kelebihan ini digunakan oleh para aktor politik untuk membentuk personal branding mereka. Sebagai contoh ketika mereka biasanya harus melakukan kampanye untuk membangun persepsi masyarakat namun dengan mengeluarkan banyak anggaran, kini mereka dapat 
melakukannya melalui media sosial dengan usaha yang kecil dan anggaran yang sedikit.

Al-Ries (1982) dan Boush (1991) menjelaskan bahwa setiap orang memiliki philosophy branding yang berbeda-beda yang menyebabkan setiap orang memiliki keunikannya tersendiri serta karakeristik pribadi yang berbeda pula (Rangkuti, 2013:5). Pembentukan personal branding dapat menggunakan personal branding pyramid yang di dalamnya terdapat empat strategi pembentukan dan pengembangan personal branding, antara lain determine who you are, determine what you do, position yourself, dan manage your brand (Rangkuti, 2013:6).

Instagram merupakan salah satu jenis media sosial yang banyak digunakan saat ini. Melansir kumparan.com, dilaporkan bahwa ada lebih dari 61.610.000 pengguna aktif Instagram di Indonesia per November 2019, dan dibenarkan oleh perusahaan analisis marketing media sosial NapoleonCat. Ini kemungkinan menjadi salah satu bukti bahwa masyarakat Indonesia telah bergantung pada media sosial untuk mendapatkan informasi.

Ganjar Pranowo merupakan salah satu aktor politik yang aktif di media sosial. Gubernur Provinsi Jawa Tengah itu telah memiliki 3.1 juta pengikut di akun Instagram (@ganjar_pranowo) dengan 3.987 kiriman per tanggal 29 Oktober 2020. Ganjar Pranowo tidak hanya sekedar berinteraksi dengan masyarakatnya di Instagram, tetapi ia juga membawa ciri khasnya sendiri dalam beraktivitas di media sosial serta membedakannya dengan politikus lain di media sosial.

Beberapa ciri khas yang ditampilkan oleh Ganjar Pranowo melalui akun media sosial Instagramnya adalah terdapat kalimat "Tuanku ya Rakyat, Gubernur Cuma Mandat” yang terdapat pada bio Instagram miliknya. Ganjar Pranowo juga kerap membagikan potret dirinya ketika sedang beraktivitas.
Ganjar Pranowo melihat keresahan masyarakatnya, khususnya Jawa Tengah, melalui media sosial dan langsung memberikan balasan tentang aduan masyarakatnya. Edukasi politik melalui platform digital dilakukan oleh Ganjar Pranowo dengan menggunakan bahasa yang mudah dipahami masyarakat. Penggunaan bahasa tersebut dilakukan dengan alasan masyarakat kurang memahami apa yang sedang dikerjakan oleh pemerintahan karena bahasa pemerintah yang kurang dapat dicerna oleh masyarakat. Media sosial dimanfaatkan oleh Ganjar Pranowo sebagai media untuk memudahkan komunikasi dua arah dengan masyarakatnya dengan membawa ciri khas yang dimilikinya dan membentuk image tentang dirinya yang kemudian akan memudahkannya dalam melakukan komunikasi politik. Cara terbaik untuk menjelaskan pentingnya media sosial untuk personal branding adalah seperti yang dijelaskan oleh Jayson Demers yakni jika konten adalah bahan bakar untuk merek pribadi, media sosial adalah mesinnya (Petruca, 2016).

Artikel ini bertujuan untuk menjelaskan strategi-strategi personal branding yang dilakukan oleh Ganjar Pranowo untuk membangun komunikasi politik melalui unggahannya di media sosial Instagram berdasarkan empat strategi pembentukan dan pengembangan personal branding yang terdiri dari determine who you are, determine what you do, position yourself, dan manage your brand.

\section{Metode Penelitian}

Artikel ini menggunakan pendekatan deskriptif kualitatif dimana pendekatan ini memfokuskan diri pada sisi tertentu dari suatu fenomena. Moleong (2012:6) menjelaskan tujuan dari pendekatan kualitatif adalah untuk memahami fenomena mengenai apa yang dialami oleh subjek penelitian. Sedangkan Rakhmat (2009:25) menyebutkan beberapa tujuan dari penelitian deskriptif, antara lain untuk mengumpulkan informasi- 
informasi bersifat aktual yang menggambarkan fenomena yang ada secara terperinci, mengidentifikasi atau memeriksa masalah dan kondisi praktik-praktik yang berlaku dalam fenomena, membuat perbandingan, dan untuk menentukan apa yang akan dilakukan oleh seseorang dalam menghadapi masalah dan belajar dari pengalaman untuk memantapkan keputusan dan rencana di masa yang akan datang. Metode kualitatif akan meneliti secara mendalam dan menghasilkan data-data yang bersifat deskriptif dan dapat dapat memberi pemahaman mengenai hal-hal yang berkaitan dengan subjek penelitian. Pendekatan deskriptif kualitatif sesuai dengan tujuan dari artikel ini yakni untuk melihat fenomena pemanfaatan media sosial oleh aktor politik untuk membangun personal branding agar mempermudah dalam melakukan komunikasi politik.

Pada penelitian ini, penulis masuk sebagai partisan fenomena yakni dalam penelitian ini penulis menjadi pengikut di media sosial Instagram milik Ganjar Pranowo. Data penelitian dikumpulkan melalui observasi pada unggahan-unggahan Ganjar Panowo di media sosial Instagram dan studi literature yang berkaitan dengan tema penelitian. Data tersebut kemudian dianalisis dan dibahas menggunakan teknik kualitatif dengan menjabarkan temuan-temuan data yang diperoleh dan kemudian akan ditarik suatu kesimpulan.

\section{Hasil Penelitian dan Pembahasan}

Aeker (1997) menjelaskan pengertian brand sebagai sebuah janji seorang penjual untuk secara konsisten memberikan nilai, fitur, manfaat, dan kinerja tertentu kepada calon pembelinya, sehingga merek tersebut dapat memberikan semua hal yang telah dijanjikan sebelumnya (Romadhan, 2018). Ada 4 jenis Brand yang perlu diketahui, antara lain yang pertama product brand, yakni brand yang berhungan dengan produk. Kedua Company brand, yakni brand yang berhubungan dengan perusahaan maupun organisasi.
Ketiga Personal brand, yakni brand yang berhubungan dengan personal atau individu, dan yang keempat adalah brand destination atau brand yang berhubungan dengan tempat atau tujuan.

Personal branding mencakup penangkapan dan promosi dari kekuatan dan keunikan individu kepada target audiensnya (Kaputa, 2005; Schwabel, 2009; Shepherd, 2005; Labreque, Markos, \& Milne, 2011; Karaduman, 2013). Montoya dalam (Rangkuti, 2013:3) menjelaskan bahwa personal branding adalah identitas personal yang mampu memunculkan persepsi di benak audiens mengenai nilai dan kualitas yang dibawa oleh pemilik nama tersebut. Al-Ries (1982) dan Boush (1991) menjelaskan bahwa setiap orang memiliki philosophy branding yang berbeda-beda yang menyebabkan setiap orang memiliki keunikannya tersendiri serta karakeristik pribadi yang berbeda pula. Pembentukan personal branding dapat menggunakan personal branding pyramid yang di dalamnya terdapat empat strategi pembentukan dan pengembangan personal branding, antara lain determine who you are, determine what you do, position yourself, dan manage your brand (Rangkuti, 2013:6).

Determine Who You Are merupakan strategi awal untuk menentukan siapakah diri kita yang sebenarnya. Personal Branding sendiri merupakan refleksi dari individu yang sudah melekat pada objek tersebut, oleh karena itu personal branding dapat diidentifikasikan dengan menanyakan pada diri sendiri apa yang harus dilakukan agar dapat memiliki perbedaan dengan orang lain. Strategi ini dapat dilakukan dengan melakukan analisis SWOT, yaitu menganalisis kekuatan, kelemahan, peluang, dan ancaman. Determine What You Do (menentukan apa yang akan dikerjakan) dapat dilakukan dengan mengidentifikasi keunikan dan kekuatan utama yang sudah kita miliki yang berkaitan dengan sesuatu yang akan kita kerjakan. Personal Branding tidak harus dilakukan dengan cara melakukan sesuatu yang menarik perhatian, namun memberikan perhatian lebih 
pada pemahaman terhadap nilai yang telah dimiliki dengan pertimbangan apakah nilai tersebut sesuai dan bermanfaat bagi orang lain atau tidak. Position Yourself (memposisikan diri) yaitu strategi mengidentifikasi karakteristik dan kualitas diri yang membedakan diri kita dengan pesaing. Agar positioning bertambah kuat, dapat dilakukan dengan cara menyamakan nilai-nilai yang dimiliki diri sendiri dengan nilai-nilai yang dimiliki target agar terjadi keselarasan hubungan dengan tujuan bisnis yang saling mendukung. Al-Ries (1982) menyebutkan bahwa strategi positioning yang sama dengan pesaing maka tidak disebut dengan strategi. Manage Your Brand yakni mengelola brand yang sedang dibentuk. Kunci dari mengelola sebuah brand adalah "word of mouth" dimana personal branding harus selalu mampu memberikan kepercayaan ke dalam benak setiap konsumen. Semakin banyak konsumen yang percaya, maka semakin cepat pula kekuatan dari "word of mouth" menyebar dengan tanpa mengeluarkan biaya promosi (Rangkuti, 2013:9).

Ganjar Pranowo merupakan Gubernur Jawa Tengah yang aktif menggunakan media sosial. Pada setiap kiriman yang ia bagikan, ia membagikan informasi, penanganan suatu masalah, memberi himbauan, memberi tahu kegiatan yang dilakukan pemerintah, maupun hanya sekedar menyapa masyarakat melaui kiriman tentang aktivitas yang dilakukannya.

"Tuanku ya Rakyat, Gubernur Cuma mandat", adalah slogan yang disematkan oleh Ganjar Pranowo di bio Instagram miliknya. Slogan tersebut menjadi strategi awal Ganjar dalam membangun personal brand melalui media sosial, yakni determine who you are. Secara jelas Ganjar Pranowo melalui slogan tersebut akan membentuk dirinya menjadi seorang pemimpin yang menghormati rakyatnya selayaknya seseorang yang menghormati tuannya. Ganjar Pranowo secara tersurat dan tersirat akan melayani rakyatnya dan memastikan kemakmuran setiap masyarakatnya terlaksana. Ganjar menganggap bahwa jabatan sebagai Gubernur hanyalah sebagai sebuah mandat saja dan dengan jabatan tersebut ia diwajibkan untuk melayani masyarakat sebagai tuannya. Slogan tersebut menjadi salah satu ciri yang membedakan Ganjar dengan politisi lain yang juga aktif di media sosial.

Gambar 1. "Tuanku ya Rakyat, Gubernur Cuma Mandat” dala Bio Instagram milik Ganjar Pranowo

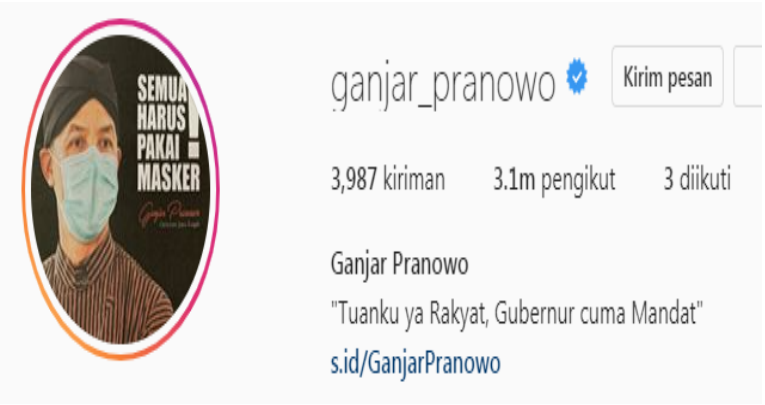

Sumber: Instagram.com/ganjar_pranowo

Refleksi dari slogan tersebut dibuktikan oleh Ganjar Pranowo dengan cara merespon setiap aduan dan kritik yang dikirimkan oleh masyarakatnya. Determine what you do merupakan strategi pembentukan personal brand dengan menentukan apa yang akan kita kerjakan untuk menunjang strategi pembentukan personal brand yang pertama. Pada strategi ini, Ganjar Pranowo mengidentifikasi kekuatan utama dan keunikan yang dimilikinya.

Tindakan Ganjar yang merespon setiap aduan masyarakatnya di media sosial memberi peluang bagi masyarakatnya untuk dengan mudah berbincang dengan pemimpinnya dan mendapat respon langsung dari apa yang mereka keluh kesahkan. Dalam membalas aduan masyarakatnya, Ganjar menggunakan bahasa yang merakyat dan mudah diterima oleh masyarakatnya. Alasannya adalah agar masyarakat merasa lebih dekat dengan pemimpinnya dan tidak merasa canggung. Penggunaan bahasa yang sama dengan masyarakatnya memungkinkan terciptanya interaksi yang lebih hangat dan tidak ada benteng 
antara pemimpin dan masyarakat seperti yang biasa terjadi.

Gambar 2. Ganjar Pranowo merespon aduan dari salah satu rakyatnya melalui kolom komentar

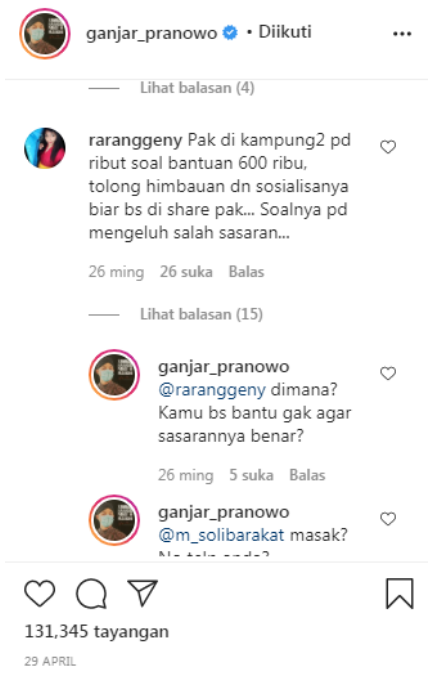

Sumber: Instagram.com/ganjar_pranowo

Tindakan lain yang dilakukan oleh Ganjar Pranowo untuk membangun personal brand melalui media sosial adalah dengan rajin mengangkat isu-isu yang sedang mejadi permasalahan di wilayahnya untuk dijadikan konten di media sosialnya. Namun yang membedakannya dengan cara politikus lain dalam mengangkat isu-isu di wilayahnya adalah Ganjar Pranowo melakukannya dengan cara yang unik. Seperti contoh ketika wilayahnya sedang dilanda wabah virus Corona, Ganjar mengkampanyekan gerakan cuci tangan terus dengan cara mengenakan kaos bertulisakan "Cuci Tangan terus biar gak kena Corona Virus" dengan potret ia mengenakan kaos tersebut ketika sedang bersepada sambil berkampanye tentang himbauan menjaga kebersihan. Cara Ganjar Pranowo dalam membentuk personal brand pada strategi determine what you do membuat image Ganjar menjadi lebih terbentuk dan ditangkap oleh masyarakat. Masyarakat akan dapat menilai seperti apakah sosok pemimpinnya melalui cara Ganjar merespon aduan masayarakatnya, penggunaan bahasa ketika sedang berinteraksi dengan masyaraktatnya, dan gerakan Ganjar dalam merespon isu-isu yang menjadi permasalahan di wilayahnya. Ganjar Pranowo mencoba untuk menjadi lebih dekat dengan masyarakat dan membangun image baik di mata masyarakatnya sehingga komunikasi politik yang dilakukan oleh Ganjar akan menjadi lebih mudah tersampaikan pesannya.

\section{Gambar 4. Ganjar Pranowo mengenakan} kaos hitam bertuliskan “Cuci Tangan terus biar gak kena Corona Virus"

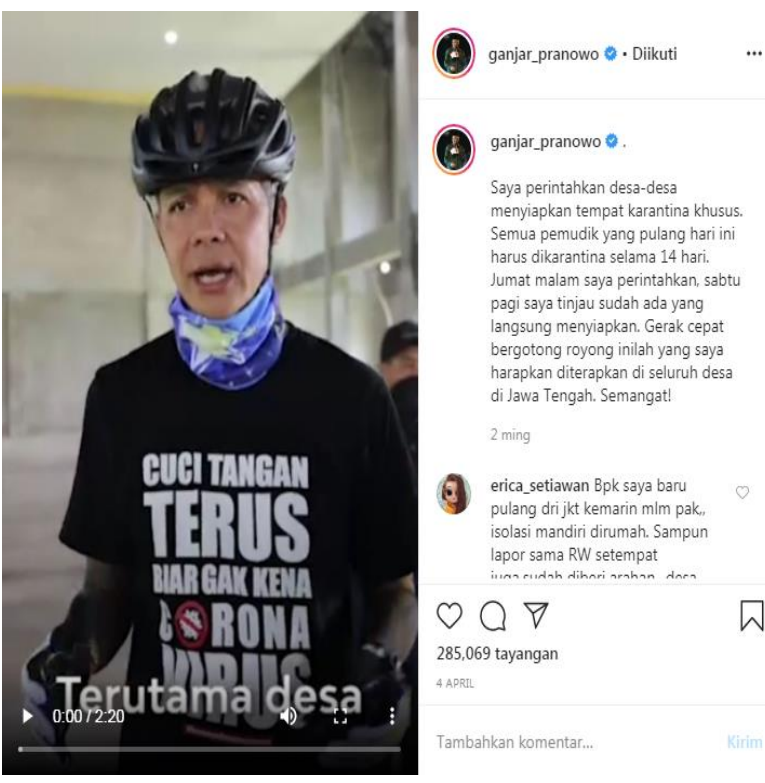

Sumber: Instagram.com/ganjar_pranowo

Strategi pembentukan personal brand yang ketiga adalah position yourself. Ganjar Pranowo melalui penentuan diri dan tindakan yang dilakukannya mencoba untuk memposisikan dirinya sebagai pemimpin yang unik, cepat tanggap dalam merespon aduan masyarakatnya, merendah dan dekat dengan masyarakat, serta tanggap dengan persoalan yang terjadi di wilayahnya. Ganjar memposisikan dirinya seolah-olah setara dengan masyarakatnya namun dia mempunyai privilege untuk membantu menyelesaikan aduan dan laporan masyarakat. Keunikan dan cara pendekatannya kepada masyarakat menjadikannya sebagai politikus yang berbeda dengan politikus lain.

Strategi yang terakhir adalah manage your brand. Rangkuti (2013:9) menjelaskan bahwa kunci 
penting dalam mengelola personal brand adalah "word of-mouth marketing” dan pentingnya membina networking (jaringan antar teman, kolega, klien, maupun customer). Ganjar Pranowo konsisten dalam mengunggah konten di media sosialnya dan membalas keresahan masyarakatnya. Jika dilihat dari banyaknya komentar baik yang dikirimkan oleh masyarakatnya di media sosialnya, WOM yang dilakukan oleh Ganjar Pranowo tergolong sukses. Ganjar telah meninggalkan image baik di benak masyakatnya dan itu berdampak pada kemudahan Ganjar Pranowo dalam berkomunikasi politik.

\section{Gambar 5. Komentar masyarakat} mengenai Ganjar Pranowo di kolom komentar media sosial Instagramnya

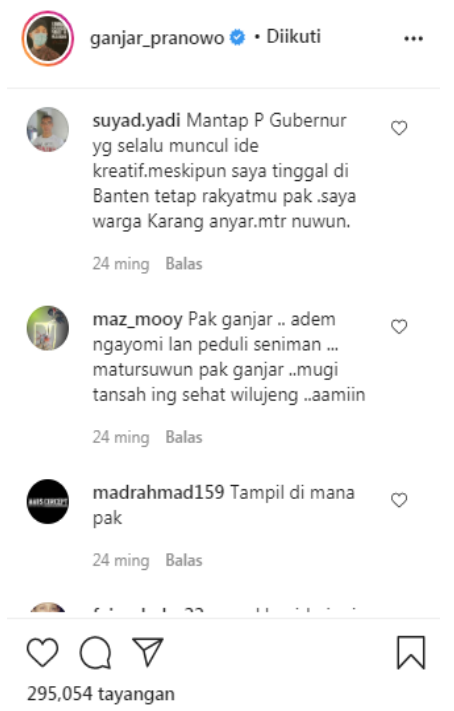

Sumber: Instagram.com/ganjar_pranowo

\section{Penutup}

Pembentukan personal brand menjadi sesuatu yang penting bagi politikus agar memudahkan mereka untuk berkomunikasi dengan masyarakatnya. Personal brand yang sukses akan membentuk image yang baik dan membangun kepercayaan masyarakat terhadap dirinya. Personal branding mampu memberikan kontrol tentang persepsi atau cara pandang orang lain terhadap diri seseorang. Oleh karena itu, orang yang melakukan personal branding akan dapat mempengaruhi dan mengontrol pandangan ataupun persepsi orang lain terhadap dirinya sesuai yang dikehendakinya. Ganjar Pranowo telah melakukan strategi pembentukan personal branding melalui empat strategi yakni determine who you are, determine what yo do, position yourself, dan manage your brand. Strategi-strategi tersebut sukses membuat Ganjar Pranowo menjadi lebih dekat dengan masyarakat dan membangun kepercayaan masyarakat terhadap dirinya. Komunikasi politik yang dilakukan oleh Ganjar Pranowo menjadi lebih mudah diterima oleh masyrakatnya sebab image baik tentang dirinya yang sudah tertanam di benak masyarakatnya. Media sosial memberikan peluang bagi Ganjar Pranowo untuk berkomunikasi dengan para pengikutnya dan membangun komunikasi politik melalui personal branding yang dibentuknya. Usaha Ganjar Pranowo dalam membangun personal branding melalui media sosial membawa hasil yang memengaruhi image Ganjar Pranowo di mata masyarakat terbukti dengan dipilihnya Ganjar Pranowo sebagai Gubernur Jawa Tengah selama dua periode.

\section{Daftar Pustaka}

Aeker, D. (1997). Manajemen Ekuitas Merek (Alih Bahasa: Aris Ananda). Jakarta: Mitra Utama.

Anshari, F. (2013). Komunikasi Politik di Era Media Sosial. Jurnal Komunikasi, Vol 8 No 1, hal. 91101.

Anshori, A. (2018). Pengaruh Iklan Politik Terhadap Persepsi Pemilih Kota Medan Tahun 2018. Jurnal Interaksi, Vol 2 No 2, hal. 132-144.

Dalla-Camina, M. (2016). What Do You Want To Be Known For? Diakses dari: https://www.huffpost.com/entry/what-do-youwant-to-be-known-for_b_12112598

Effendy, O.U. (2003). Ilmu, Teori dan Filsafat Komunikasi. Bandung: Citra Aditya Bakti.

Kaplan, A, \& Haenlein, M. (2010). Users of The World, Unite! The Challenges and Opportunities of Social Media. Business Horizons, Vol 53 No 1, hal. 59-68.

Kaputa, C. (2005). UR a Brand! How Smart People Brand Themselves for Business Success. California: Davies-Black Publishing, USA.

Karaduman, İ. (2013). The Effect of Social Media on Personal Branding Efforts of Top Level Executives. Procedia - Social and Behavioral Sciences, Vol 99, hal. 465-473.doi: 10.1016/j.sbspro.2013.10.515

Labreque, L. I., Markos, E., \& Milne, G. R. (2011). 
Online Personal Branding: Processes, Challenges, and Implications. Journal of Interactive Marketing, Vol 25 No 1, hal. 37-50.

Moleong, L. J. (2012). Metodologi Penelitian Kualitatif. Bandung: Remaja Rosdakarya.

Mondry, \& Risman Sikumbang. (2016). Pemahaman Teori dan Praktik Jurnalistik (2nd ed.). Bogor: Ghalia Indonesia.

Petruca, I. (2016). Personal Branding Through Social Media. International Journal of Communication Research, Vol 6 No 4, hal. 389-392. doi: 10.4018/978-1-4666-9593-1.les4

Rakhmat, J. (2009). Metode Penelitian Komunikasi Dilengkapi Contoh Analisis Statistik. Bandung: Remaja Rosdakarya.

Rangkuti, F. (2013). Strategi Semut Melawan Gajah. Jakarta: PT. Gramedia Pustaka Utama.
Romadhan, M. I. (2018). Personal Branding Jokowi Dalam Mempertahankan Brand Image Melalui Video Blog Youtube. MetaCommunication; Journal of Communication Studies, Vol 3 No 2, hal. 76-93.

Schwabel, D. (2009). Me 2.0: A Powerful Way To Achieve Brand Success. New York: Kaplan Publishers, USA.

Shepherd, I. D. . (2005). From Cattle and Coke to Charlie: Meeting The Challenge of Self Marketing and Personal Branding. Journal of Marketing Management, Vol 21 No 5-6, hal. 589-606.

Susanto, E. H. (2017). Media Sosial Sebagai Pendukung Jaringan Komunikasi Politik. Jurnal ASPIKOM, Vol 3 No 3, hal. 379. 